\title{
Effect of Nigella sativa supplementation on human lipids: systematic review
}

\author{
Redhwan Ahmed Al-Naggar ${ }^{*}$, Muhamed T. Osman ${ }^{2}$, Isa Naina Mohamed ${ }^{3}$, Khairun Nain Bin Nor Aripin ${ }^{4}$, \\ Mahfoudh A. M. Abdulghani ${ }^{5}$ \\ ${ }^{1}$ Faculty of Medicine, Universiti Teknologi MARA (UiTM), Selangor, Malaysia, ${ }^{2}$ Faculty of Medicine and Defence Health, National Defence University \\ of Malaysia. (UPNM), Kuala Lumpur, Malaysia, ${ }^{3}$ Faculty of Medicine, Universiti Kebangsaan Malaysia (The National University of Malaysia), Malaysia, \\ ${ }^{4}$ Faculty of Medicine and Health Sciences, Universiti Sains Islam Malaysia, Malaysia, ${ }^{5}$ College of Pharmacy, Qassim University, Saudi Arabia.
}

\begin{tabular}{|c|c|}
\hline ARTICLE INFO & ABSTRACT \\
\hline Article history: & \multirow{7}{*}{$\begin{array}{l}\text { Nigella sativa }(N S) \text { is widely used in traditional medicine and several studies have been conducted to reveal NS } \\
\text { effects on different medical disorders including hyperlipidemia. Since hyperlipidemia is a common risk factor } \\
\text { for the development of cardiovascular illness. We evaluated the effects of } N S \text { supplementation on lipid profile in } \\
\text { clinical trial performed among humans. A search on published studies was done by using databases including } \\
\text { Scopus, PubMed, Google Scholar, Thomas Reuters Web of Science, and CINAHIL. Terms searched included } \\
\text { "Nigella sativa, Black seed, Black cumin, Triglycerides, Cholesterol, Lipoproteins". Initially } 432 \text { articles were } \\
\text { extracted. However, four hundred eighteen papers were unrelated, reviews, animal studies, combined and } \\
\text { duplicated studies were excluded, and finally only fourteen articles were eligible for this review. After analysing } \\
14 \text { articles including } 738 \text { participants from different countries and nations. Results of these clinical trials } \\
\text { revealed that Nigella sativa is effective to change the lipid profile significantly in different conditions. This } \\
\text { systematic review revealed that Nigella sativa supplementation might be effective in hyperlipidemic control in } \\
\text { humans and seems potential target of future drug for hyperlipidemic conditions. }\end{array}$} \\
\hline Received on: 07/01/2017 & \\
\hline Accepted on: 13/03/2017 & \\
\hline Available online: $30 / 04 / 2017$ & \\
\hline & \\
\hline & \\
\hline lipids, lipid profile. & \\
\hline
\end{tabular}

\section{INTRODUCTION}

Hyperlipidemia is a common risk factor for the development of cardiovascular illness (Graham et al., 2007). Increased serum total cholesterol concentrations are directly associated with an increased risk for coronary heart disease (Navar-Boggan et al., 2015). Pharmacologic treatment used for treating high-risk persons with lipid-lowering drugs include3hydroxy-3-methylglutaryl coenzyme A reductase inhibitors (statins), bile acid sequestrants, fibrates, and nicotinates (Last AR et al., 2011). None of the above pharmacologic options are free of adverse effects (Maron et al. 2000), and some have been associated with potential carcinogenicity (Newman and Hulley,

\footnotetext{
* Corresponding Author

Redhwan Ahmed Al-Naggar, Faculty of Medicine, Universiti Teknologi MARA (UiTM), Jalan Hospital, 47000 Sg. Buloh, Selangor, Malaysia. Email: radhwan888@yahoo.com
}

1996). Effective treatment with a harmless for lowering cholesterol levels would therefore be of considerable interest. For the past decade non-pharmacologic treatment has been by the Adult Treatment Panel III (ATP III) of the National Cholesterol Education Program has recommended as initial therapy in most patients with hyperlipidemia (Expert Panel, 2011). Nigella sativa among the best rated evidence based herbal medicines (Ahmad et al., 2013). Nigella sativa (NS) (Family Ranunculaceae) is a widely used medicinal plant around the world. It is very popular in various traditional systems of medicine like Unani, Ayurveda, Siddha and Chinese.

Seeds and oil have a long history of folklore usage in various systems of medicines and food. The seeds of NS have been widely used in the treatment of different diseases and illnesses. In Islamic literature, it is considered as one of the greatest forms of healing medicine. It has been recommended for using on regular basis in Tibb-e-Nabwi (Prophetic Medicine). 
It has been widely used as antihypertensive, liver tonics, diuretics, digestive, anti-diarrheal, appetite stimulant, analgesics, anti-bacterial and in skin disorders. Extensive studies on NS have been carried out by various groups of researcher and a wide spectrum of its pharmacological actions have been explored which may include antidiabetic, anticancer, immunomodulator (Hmza et al., 2013), analgesic, antimicrobial, anti-inflammatory, spasmolytic, bronchodilator, hepato-protective, renal protective, gastro-protective, antioxidant properties (Ahmad et al., 2013). The seeds of NS are widely used in the treatment of numerous diseases like bronchitis, asthma, diarrhea, rheumatism and skin disorders. It is also has been reported that used as liver tonic, digestive, antidiarrheal, appetite stimulant, emmenagogue, to increase milk production in nursing mothers to fight parasitic infections, and to support immune system (Goreja, 2003; Khaled, 2009; Assayed, 2010; Boskabady et al., 2010; Abdel-Zaher et al., 2011; AbdelSalam, 2012). Most of the therapeutic properties of this plant are due to the presence of thymoquinone (TQ) which is a major active chemical component of the essential oil. Black seeds are also used in food like flavoring additive in the breads and pickles because it has very low level of toxicity (Al-Ali et al., 2008). There are a few review articles that have surveyed the effect of $N$. sativa on some diseases. However, we are going to conduct a systematic review of the literatures to identify relevant studies about the effect of $N$. sativa supplementation on human lipids.

\section{METHODOLOGY}

The protocol that was used in this study is the Preferred Reporting Items for Systematic Reviews and Meta-Analyses (PRISMA) checklist. A search of published studies was performed by using computer databases including Scopus, PubMed, Google Scholar, Thomas Reuters Web of Science, and CINAHIL.

\section{Literature Review:}

A systematic review of the literature was conducted to identify relevant studies about Nigella sativa and human lipids/cholestrol. To conduct a comprehensive search of health science journals, we used Medline via Ovid Medline (published between 1946 and March 2015) and CINAHL via Ebscohost (published between 1946 and 2015). The search strategy involved a combination of the following two sets of key words; (1) Nigella sativa OR black seeds OR Habutulsuda, Black cumin OR thymoquinone; (2) Lipids OR cholesterol OR triglyceride OR hyperlipidemia.

\section{Inclusion criteria}

1. The effect of Nigella sativa on human lipids changes.

2. Clinical trial.

\section{Exclusion criteria}

1. Animal studies.

2. Review studies.
3. The effect of Nigella sativa on unrelated blood or clinical parameters.

4. The effect of Nigella sativa in combination with other plants or exercise.

5. Duplicated studies.

\section{Selection of Research Articles}

The results were limited to studies that were published in English language that included abstracts. To be included, studies had to (1) report the association or effect of Nigella sativa and human lipid changes. Papers were excluded if the studies were related to reviews, news, letter, editorials, or case studies.

\section{Data Extraction and Management}

We selected papers to be included in the review in three phases. First, we excluded any paper that did not match the inclusion criteria based solely on the title. Second, we screened all the abstracts of the remaining papers and then excluded a second group of papers that did not meet our inclusion criteria. Lastly, we read the remaining papers from the second phase to exclude any paper that did not meet our inclusion criteria. After the initial screening of the titles and abstracts, duplicates were removed and the remaining papers were again screened by at least two reviewers. The inclusion of the full papers into the review had to be agreed by at least two reviewers before the data extraction phase. Any discrepancies were resolved through discussion between the reviewers. Initially, 432 articles were extracted. After reviewing their titles and abstracts and removing unrelated, animal, and review studies, 312 articles (Medline; 206, Scopus; 90, EBSCO; 16) were retrieved for further evaluation. After excluding the animal studies, reviews, removal of abstracts due to duplicates and unrelated studies. Finally, 14 studies were considered eligible for our review [Table 1].

Table 1: Process of study selection.

\begin{tabular}{ll}
\hline Process & $\begin{array}{l}\text { Selected } \\
\text { studies }\end{array}$ \\
\hline Initial search & $\begin{array}{l}432 \text { papers } \\
312 \text { papers }\end{array}$ \\
$\begin{array}{l}\text { After exclusion of studies that were unrelated to this } \\
\text { study. }\end{array}$ & 67 papers \\
After exclusion of animal studies & 21 papers \\
After exclusion of review studies & 18 papers \\
After exclusion of combined studies & 14 papers \\
$\begin{array}{l}\text { After exclusion of duplicated studies (eligible for our } \\
\text { review). }\end{array}$ \\
\hline
\end{tabular}

\section{RESULTS}

Data extraction was performed independently from 14 studies and in a standardized manner with the use of a data collection form. We recorded the following data from the studies: (1) the type of study, (2) a brief description of the sample/population of the study; (3) a brief description of the methods used in the study; (4) the brief description of the results of the study; (5) comments and conclusion of the study (6) complications if any. 
Table 2: Characteristics of human studies that eligible to the study.

\begin{tabular}{|c|c|c|c|c|c|c|c|}
\hline & Study/country & $\begin{array}{l}\text { Type of } \\
\text { study }\end{array}$ & $\begin{array}{c}\text { Sample/ } \\
\text { population }\end{array}$ & Methodology & Results & $\begin{array}{c}\text { Comments or } \\
\text { outcomes }\end{array}$ & complications \\
\hline 1. & $\begin{array}{l}\text { Heshmati et } \\
\text { al. 2015/ Iran }\end{array}$ & $\begin{array}{l}\text { double- } \\
\text { blind } \\
\text { placebo- } \\
\text { controlled } \\
\text { randomized } \\
\text { clinical trial }\end{array}$ & $\begin{array}{l}\text { T2DM } \\
(\mathrm{n}=72)\end{array}$ & $\begin{array}{l}\text { Randomly divided into two } \\
\text { groups using a block } \\
\text { randomization procedure, based } \\
\text { on sex, age and duration of } \\
\text { diabetes. In every permuted block } \\
\text { of patients, two subjects were } \\
\text { allocated to each arm of the trial. }\end{array}$ & $\begin{array}{l}\text { TC }(-9.8 \%), \text { TG }(-4.3 \%), \\
\text { HDL-C }(19 \%) \text { and LDL-C } \\
(-17.6 \%) \text { changed } \\
\text { significantly in the } \\
\text { intervention group compared } \\
\text { to baseline. }\end{array}$ & $\begin{array}{l}\text { NS oil can } \\
\text { improve } \\
\text { glycemic status } \\
\text { and lipid } \\
\text { profile in } \\
\text { patients with } \\
\text { T2DM. }\end{array}$ & $\begin{array}{l}\text { No } \\
\text { complications } \\
\text { caused by NS } \\
\text { were observed. }\end{array}$ \\
\hline 2. & $\begin{array}{l}\text { Ibrahim et al. } \\
\text { 2014/ } \\
\text { Malaysia }\end{array}$ & $\begin{array}{l}\text { Experiment } \\
\text { al study } \\
(\mathrm{CT})\end{array}$ & $\begin{array}{l}37 \text { Women } \\
\text { (45-69 year, } \\
\text { menopause }\end{array}$ & $\begin{array}{l}18 \text { respondents were assigned to } \\
\mathrm{NS}, 17 \text { respondents placebo } \\
\text { group, the case group were } \\
\text { received NS for } 2 \text { months }\end{array}$ & $\begin{array}{l}\text { Significant decrease in the } \\
\text { development of } \\
\text { hyperlipidemia among } \\
\text { menopausal women in NS } \\
\text { treatment group compared to } \\
\text { placebo group. }\end{array}$ & $\begin{array}{l}\text { NS has } \\
\text { beneficial } \\
\text { effects on lipid } \\
\text { profile in } \\
\text { menopause } \\
\text { women. }\end{array}$ & $\begin{array}{l}\text { No } \\
\text { complications } \\
\text { caused by NS } \\
\text { were observed. }\end{array}$ \\
\hline 3. & $\begin{array}{l}\text { Qibi et al. } \\
2006 / \text { Iraq }\end{array}$ & $\begin{array}{l}\text { Experiment } \\
\text { al study }\end{array}$ & $\begin{array}{l}10 \text { Healthy } \\
\text { population }\end{array}$ & $\begin{array}{l}\text { Ten healthy volunteer age ranged } \\
20-49 \text { years. Non-smoker- non } \\
\text { hypertensive patients, non DM, } \\
\text { no CVD, no other medication that } \\
\text { can influence lipid metabolism. } \\
750 \text { mg twice a day for } 28 \text { days. }\end{array}$ & $\downarrow \mathrm{TG}, \downarrow \mathrm{LDL}, \downarrow \mathrm{TC}, \uparrow \mathrm{HDL}$ & $\begin{array}{l}\text { NS is a } \\
\text { favorable effect } \\
\text { on lipid profile } \\
\text { of healthy } \\
\text { individuals }\end{array}$ & $\begin{array}{l}\text { No } \\
\text { complications } \\
\text { caused by NS } \\
\text { were observed. }\end{array}$ \\
\hline 4. & $\begin{array}{l}\text { Najmi et al. } \\
\text { 2012/India }\end{array}$ & $\begin{array}{l}\text { Experiment } \\
\text { al study }\end{array}$ & $\begin{array}{l}80 \text { Patients of } \\
\text { metabolic } \\
\text { syndrome/ } 52 \\
\text { males and } 38 \\
\text { females. } \\
\text { Age } 20 \text { to } 70\end{array}$ & $\begin{array}{l}\text { Group } 1(\mathrm{n}=40) \text { were advised to } \\
\text { take metformin } 500 \mathrm{mg} \text { twice a } \\
\text { day, atorvastatin } 10 \mathrm{mg} \text { once a } \\
\text { dayAsprin } 150 \mathrm{mg} \text { for a period of } \\
8 \text { weeks; Group } 2 \text { (above } \\
\text { medication)+500mg capsule of } \\
\text { NS }\end{array}$ & $\downarrow \downarrow \mathrm{TG}, \downarrow \mathrm{LDL}, \downarrow \mathrm{TC}, \uparrow \mathrm{HDL}$ & $\begin{array}{l}\text { NS can be used } \\
\text { as add on drug } \\
\text { therapy in } \\
\text { metabolic } \\
\text { syndrome } \\
\text { patients. }\end{array}$ & $\begin{array}{l}\text { No } \\
\text { complications } \\
\text { caused by NS } \\
\text { were observed. }\end{array}$ \\
\hline 5. & $\begin{array}{l}\text { Tasawar et } \\
\text { al. } \\
\text { 2011/Pakista } \\
\text { n }\end{array}$ & $\begin{array}{l}\text { Experiment } \\
\text { al study }\end{array}$ & $\begin{array}{l}80 \text { patients } \\
\text { with stable } \\
\text { coronary } \\
\text { artery disease }\end{array}$ & $\begin{array}{l}\text { 1)The interventional group given } \\
\text { Nigella sativa seeds powder } \\
500 \mathrm{mg} / \text { daily and statin (10-20 } \\
\text { mg) for } 108 \text { days. } \\
\text { 2)noninterventional group given } \\
\text { statin (10-20mg/daily) daily only. }\end{array}$ & $\begin{array}{l}\downarrow \mathrm{TG}, \downarrow \mathrm{LDL}, \downarrow \mathrm{TC}, \uparrow \mathrm{HDL}, \\
\downarrow \mathrm{VLDL}\end{array}$ & $\begin{array}{l}\text { Nigella sativa } \\
\text { is effective to } \\
\text { change the } \\
\text { lipid profile } \\
\text { significantly }\end{array}$ & $\begin{array}{l}\text { No } \\
\text { complications } \\
\text { caused by NS } \\
\text { were observed. }\end{array}$ \\
\hline 6. & $\begin{array}{l}\text { Kaatabi et al. } \\
\text { 2012/ KSA }\end{array}$ & $\begin{array}{l}\text { Open-label, } \\
\text { second } \\
\text { phase trial } \\
\text { study }\end{array}$ & $\begin{array}{l}94 \text { DM } \\
\text { patients }(43 \\
\text { males and } 51 \\
\text { females) with } \\
\text { type 2, } \\
\text {. }\end{array}$ & $\begin{array}{l}94 \text { patients were divided into } 3 \\
\text { groups through simple random } \\
\text { sampling and were administrated } \\
3 \text { different oral doses of NS ( } 1 \mathrm{~g} \text {, } \\
2 \mathrm{~g}, 3 \mathrm{~g} \text { per day for } 12 \text { weeks) }\end{array}$ & $\begin{array}{l}\text { Patients ingested 2g/day NS } \\
\text { significantly decline in TC, } \\
\text { TG, and LDL, and a } \\
\text { significant elevation in HDL. }\end{array}$ & $\begin{array}{l}\text { NS } \\
\text { supplementatio } \\
\mathrm{n} \text { at a dose of } \\
2 \mathrm{~g} / \text { day for } 12 \\
\text { weeks may } \\
\text { improve the } \\
\text { dyslipidemia } \\
\text { associated with } \\
\text { type } 2 \text { DM. }\end{array}$ & $\begin{array}{l}\text { No } \\
\text { complications } \\
\text { caused by NS } \\
\text { were observed. }\end{array}$ \\
\hline 7. & $\begin{array}{l}\text { Najmi et al. } \\
\text { 2008/India }\end{array}$ & $\begin{array}{l}\text { Experiment } \\
\text { al study }\end{array}$ & $\begin{array}{l}60 \text { patients } \\
\text { with } \\
\text { metabolic } \\
\text { syndrome }\end{array}$ & $\begin{array}{l}60 \text { patients divided into } 2 \text { groups } \\
\text { of } 30 \text { each. } \\
\text { 1) } 30 \text { pts were advised to take } \\
\text { (atorvastatin } 10 \mathrm{mg} \text { once a day } \\
\text { and metformine } 500 \mathrm{mg} \text { twice a } \\
\text { day for a period of six weeks. } \\
\text { 2)3o pts were advised to take } \\
\text { (atorvastatin } 10 \mathrm{mg} \text { once a day } \\
\text { and metformine } 500 \mathrm{mg} \text { twice a } \\
\text { dayfor a period of six weeks and } \\
\text { N. Sativa } 2.5 \mathrm{ml} \text { (oil)twice daily. }\end{array}$ & $\begin{array}{l}\text { The treatment group showed } \\
\text { significant improvement with } \\
\text { reference to total xcholestrol, } \\
\text { low density lipoprotein, } \\
\text { (LDL-C) }\end{array}$ & $\begin{array}{l}\text { NS oil has a } \\
\text { significant } \\
\text { activity in } \\
\text { dyslipidemic } \\
\text { patients. }\end{array}$ & $\begin{array}{l}\text { No } \\
\text { complications } \\
\text { caused by NS } \\
\text { were observed. }\end{array}$ \\
\hline 8. & $\begin{array}{l}\text { Bhatti and } \\
\text { Rehman, } \\
\text { 2009/ } \\
\text { Pakistan }\end{array}$ & $\begin{array}{l}\text { Experiment } \\
\text { al study }\end{array}$ & $\begin{array}{l}10 \text { pts } \\
\text { Hypercholest } \\
\text { erolemic } \\
\text { patients ; }\end{array}$ & $\begin{array}{l}1 \mathrm{~g} \text { of SN powder before breakfast } \\
\text { was orally administered for } 2 \\
\text { months. }\end{array}$ & $\downarrow \mathrm{TG}, \downarrow \mathrm{LDL}, \downarrow \mathrm{TC}, \uparrow \mathrm{HDL}$ & $\begin{array}{l}\text { The NS modify } \\
\text { the plasma } \\
\text { lipid profile in } \\
\text { Hypercholester } \\
\text { olemic patients }\end{array}$ & $\begin{array}{l}\text { No } \\
\text { complications } \\
\text { caused by NS } \\
\text { were observed. }\end{array}$ \\
\hline 9. & $\begin{array}{l}\text { Sabzghabaee } \\
\text { et al. } \\
\text { 2012/Iran }\end{array}$ & $\begin{array}{l}\text { Randomize } \\
\text { d, placebo } \\
\text { controlled } \\
\text { clinical trial }\end{array}$ & $\begin{array}{l}88 \text { subjects } \\
\text { aged }>\text { or } \\
=18 \text { years } \\
\text { with a total } \\
\text { cholesterol } \\
\text { concentration } \\
>200 \mathrm{mg} / \mathrm{dl} \\
\text { were } \\
\text { included }\end{array}$ & $\begin{array}{l}\text { According to the patients" } \\
\text { profiles number, they were } \\
\text { randomized to receive either N. } \\
\text { sativa capsules or the matching } \\
\text { placebo. Each N sativa capsule } \\
\text { contained } 500+/-10 \mathrm{mg} \mathrm{N} \text {. sativa } \\
\text { crushed seeds, and patients had to } \\
\text { take } 2 \mathrm{~g} \text { N. sativa per day for } 4 \\
\text { weeks. }\end{array}$ & $\begin{array}{l}\text { Significant decrease was } \\
\text { observed in the concentration } \\
\text { of total cholesterol }(4.78 \%) \text {, } \\
\text { Low density lipoprotein } \\
(7.6 \%) \text { and Triglyceride } \\
(16.65 \%) \text {, and this decrease } \\
\text { was more significant for TG } \\
\text { concentration. }\end{array}$ & $\begin{array}{l}\text { N. sativa may } \\
\text { have some } \\
\text { beneficial } \\
\text { therapeutic } \\
\text { effects in the } \\
\text { treatment of } \\
\text { hyperlipidemia. }\end{array}$ & $\begin{array}{l}\text { No } \\
\text { complications } \\
\text { caused by NS } \\
\text { were observed. }\end{array}$ \\
\hline
\end{tabular}




\begin{tabular}{|c|c|c|c|c|c|c|c|}
\hline 10. & $\begin{array}{l}\text { (Datau et al. } \\
\text { 2010)/Indon } \\
\text { esia }\end{array}$ & $\begin{array}{l}\text { Experiment } \\
\text { al, double } \\
\text { blinded } \\
\text { with } \\
\text { placebo } \\
\text { control, pre- } \\
\text { test and } \\
\text { post-test } \\
\text { design }\end{array}$ & $\begin{array}{l}39 \text { Subjects } \\
\text { are } 30-45 \\
\text { years old, } \\
\text { divided into } \\
\text { the } \\
\text { treatment } \\
\text { and control } \\
\text { groups, and } \\
\text { evaluated } \\
\text { weekly for } \\
3 \text { months. }\end{array}$ & & $\begin{array}{l}\text { Nigella sativa could inhibit } \\
\text { the decreasing of serum free } \\
\text { testosterone. No side effects } \\
\text { were detected in the } \\
\text { treatment group. }\end{array}$ & $\begin{array}{l}\text { It is suggested } \\
\text { that larger dose } \\
\text { and longer } \\
\text { duration of NS } \\
\text { consumption } \\
\text { will give better } \\
\text { results. }\end{array}$ & $\begin{array}{l}\text { No } \\
\text { complications } \\
\text { caused by NS } \\
\text { were } \\
\text { observed. }\end{array}$ \\
\hline 11. & $\begin{array}{l}\text { (Qidwai et } \\
\text { al. } \\
\text { 2009)/Pakist } \\
\text { an }\end{array}$ & $\begin{array}{l}\text { Randomize } \\
\text { d, double- } \\
\text { blind trial. }\end{array}$ & $\begin{array}{l}123 \\
\text { subjects, } \\
\text { Baseline } \\
\text { and after- } \\
\text { intervention } \\
\text { variables } \\
\text { recorded }\end{array}$ & $\begin{array}{l}\text { Baseline and after-intervention } \\
\text { variables recorded were the } \\
\text { following: body-mass index, waist- } \\
\text { hip ratio, blood pressure, fasting } \\
\text { blood sugar, serum lipids, serum } \\
\text { alanine aminotransferase, and } \\
\text { serum creatinine. }\end{array}$ & $\begin{array}{l}\text { Favorable impact of } \\
\text { powdered N. sativa (Kalonji) } \\
\text { seed in capsule was noted on } \\
\text { almost all variables, but } \\
\text { results were not statistically } \\
\text { significant because of small } \\
\text { sample size. }\end{array}$ & $\begin{array}{l}\text { Favorable } \\
\text { impact of } \\
\text { powdered N. } \\
\text { sativa (Kalonji) } \\
\text { seed in capsule } \\
\text { was noted on } \\
\text { almost all } \\
\text { variables, }\end{array}$ & $\begin{array}{l}\text { No } \\
\text { complications } \\
\text { caused by NS } \\
\text { were } \\
\text { observed. }\end{array}$ \\
\hline 12. & $\begin{array}{l}\text { Dehkordi, } \\
\text { Kamkhah } \\
\text { 2008/ Iran }\end{array}$ & $\begin{array}{l}\text { randomized } \\
\text {, double- } \\
\text { blind, } \\
\text { placebo- } \\
\text { controlled } \\
\text { trial }\end{array}$ & 48 subjects & $\begin{array}{l}\text { NS extract caused a significant } \\
\text { decline in the level of total and } \\
\text { low-density-lipoprotein (LDL)- } \\
\text { cholesterol relative to baseline data. }\end{array}$ & $\begin{array}{l}\text { NS extract caused a } \\
\text { significant decline in the } \\
\text { level of total and low- } \\
\text { density-lipoprotein (LDL)- } \\
\text { cholesterol relative to } \\
\text { baseline data. No } \\
\text { complications caused by NS } \\
\text { were observed. }\end{array}$ & & $\begin{array}{l}\text { No } \\
\text { complications } \\
\text { caused by NS } \\
\text { were } \\
\text { observed. }\end{array}$ \\
\hline 13. & $\begin{array}{l}\text { Bamosa et } \\
\text { al. } \\
1997 / \mathrm{KSA}\end{array}$ & $\begin{array}{l}\text { Clinical } \\
\text { trial }\end{array}$ & $\begin{array}{l}12 \text { health } \\
\text { and } 7 \\
\text { controls }\end{array}$ & $\begin{array}{l}2 \text { capsules of } 500 \mathrm{mg} \text { N.Sativa } \\
\text { twice daily . All parameters were } \\
\text { tested after } 2 \text { weeks }\end{array}$ & $\begin{array}{l}\text { Significant decrease of } \\
\text { glucose, cholesterol }\end{array}$ & $\begin{array}{l}\text { N.sativa has a } \\
\text { potential } \\
\text { reducing effect } \\
\text { on the blood } \\
\text { levels of both } \\
\text { glucose and } \\
\text { cholesterol }\end{array}$ & $\begin{array}{l}\text { No } \\
\text { complications } \\
\text { caused by NS } \\
\text { were } \\
\text { observed. }\end{array}$ \\
\hline 14. & $\begin{array}{l}\text { Ahmed et } \\
\text { al. } \\
\text { 2012)/Egypt }\end{array}$ & $\begin{array}{l}\text { Experiment } \\
\text { al study }\end{array}$ & $\begin{array}{l}66 \\
\text { subjects/D } \\
\text { M patients }\end{array}$ & $\begin{array}{l}\text { The first group included } 41 \text { patients } \\
\text { with T2DM. DM was diagnosed } \\
\text { according to the ADA, 2012. The } \\
\text { patients were chosen to be free of } \\
\text { diabetic complications. }\end{array}$ & $\begin{array}{l}\text { All subjects received oral } \\
\text { N. sativa tea ( } 5 \mathrm{gm} / \text { day) daily } \\
\text { for } 6 \text { months. This was added } \\
\text { to their oral antidiabetic } \\
\text { drugs in the patients group. }\end{array}$ & $\begin{array}{l}\text { N. sativa tea } \\
\text { improved the } \\
\text { glycemic control } \\
\text { and the lipid } \\
\text { profile and } \\
\text { increased PON- } \\
1 \text { activity in } \\
\text { T2DM. }\end{array}$ & $\begin{array}{l}\text { No } \\
\text { complications } \\
\text { caused by NS } \\
\text { were } \\
\text { observed. }\end{array}$ \\
\hline
\end{tabular}

All studies were clinical trials and have been conducted on different patients and subjects (Heshmati et al., 2015; Ibrahim et al., 2014; Qibi et al., 2006; Najmi et al., 2012; Tasawar et al., 2011; Kaatabi et al., 2012; Najmi et al., 2008; Bhatii et al., 2009; Sabzghabaee et al., 2012; Datau et al., 2010; Qidwai et al., 2009; Dehkordi et al., 2008; Bamosa et al., 1997; Ahmed et al., 2012). Information of these studies is summarized in the table 2.

The total number of subjects in these trials was 738 from different conditions and diseases as hyperlipidemia in diabetic patients (Heshmati et al., 2015; Kaatabi et al., 2012; Ahmed et al., 2012), menopausal women (Ibrahim et al., 2014), metabolic syndrome (Najmi et al., 2012; Najmi et al., 2008) and coronary heart disease (Tasawar et al., 2011). The duration of the trials was between 2 weeks- 3 months. The dose of NS supplements was between $500 \mathrm{mg}$ and $2 \mathrm{~g}$ per day and was administered orally in all studies. The age range of the participants in trials was 18-yea0rs old. Supplementation with NS oil can significantly improve lipid profile in hyperlipidemic patients with T2DM (Heshmati et al., 2015; Kaatabi et al., 2012; Ahmed et al., 2012), with menopausal women (Ibrahim et al., 2014), with metabolic syndrome (Najmi et al., 2012; Najmi et al., 2008), and with coronary heart disease (Tasawar et al., 2011). However, no complications caused by NS were observed in all studies (Table 2).

\section{DISCUSSION}

In this systematic review we have tried to evaluate the effects of Nigella sativa supplementation on lipid profile in hyperlipidemia accompanied with many conditions. Lipid profiles constitute one of the most important factors that can be changed in many diseases and are used to evaluate conditions of the patients and subjects (Mohtashami and Entezari, 2016). In our review, Nigella sativa supplement can change lipid profiles significantly in different conditions (Heshmati et al., 2015; Ibrahim et al., 2014; Qibi et al., 2006; Najmi et al., 2012; Tasawar et al., 2011; Kaatabi et al., 2012; Najmi et al., 2008; Bhatii et al., 2009; Sabzghabaee et al., 2012; Datau et al., 2010; Qidwai W et al., 2009; Dehkordi FR et al., 2008; Bamosa et al., 1997; Ahmed et al., 2012).

In one trial study (Heshmati et al., 2015) reported that NS oil decreased LDL-C and TG levels after 3months while other previous studies reported different effects of NS on lipid 
parameters. Kaatabi et al. (2012) evaluated different dosages of powdered NS (1, 2 and $3 \mathrm{~g} /$ day) in patients with type 2 diabetes. They indicated that $1 \mathrm{~g} /$ day NS increased HDL-C levels after 12 weeks. Two and $3 \mathrm{~g} /$ day of black seed decreased TC, TG and LDL-C levels and increased HDL-C concentration. However another study used supplementation with NS powder concurrent with aerobic training program decreased TC, LDL-C, TG and increased HDL-C in overweight females after 8 weeks (Heshmati et al., 2015; Farzaneh et al., 2014). Najmi et al., 2008 reported that $2.5 \mathrm{ml}$ NS oil decreased TC and LDL-C levels with no changes in HDL and TG concentrations (Farzaneh et al., 2014). These mentioned studies indicated positive effects of NS on lipid profile, but differences in dose and type of NS, dietary intake, physical activity level, baseline lipid profile, duration of intervention, type of disease, ethnicity and genotype may lead to different results.

In another trial the hypolipidemic effects of N. sativa was studied in menopausal women as part of the increasing drive to provide better insights into the effects of plant bioresources on health, and their potential use for therapy of chronic diseases (Ibrahim et al., 2014). Also, increasing numbers of women are thought to use complementary medicines for disorders associated with their menopause, and studies like these could provide evidence-based rationale for their choice of plant bioresources (Ibrahim et al., 2014). Specifically, about $75 \%$ of women were reported to be using herbal and complementary medicines in their menopausal period in place of hormone replacement therapy due to considerations on its side effects (Ibrahim et al., 2014; Tong IL, 2013).

Current study showed highly significant results noted on the lipids on healthy subjects (Qibi et al., 2006). These results support the benefit of a simple dietary element in improving lipid profile in normal people. Nigella sativa was shown to reduce TC, LDL-C and TG, while increasing HDL-C. All these effects are in favor of reducing the risks of atherosclerosis (Qibi et al., 2006; Nickavar et al., 2003).

The fatty acid composition of the black seed, including a predominance of linoleic acid (n6 polyunsaturated fatty acid) (Qibi et al., 2006; Hassanien, 2004), may explain its lipid lowering activity. Epidemiological and clinical studies have established that n6 fatty acids protect against CHD (Morikawa, 2004). These favorable results on normal people should stimulate a further work on large number of persons and in studying the effect of $N$. sativa as a lipid lowering remedy in dyslipidaemic patients on a wider scale (Qibi et al., 2006). Current study revealed the effect of Nigella sativa on FBG, PPBG, HbA1C \& lipid profile of metabolic syndrome patients with poor glycemic control (HbA1C $>7$ \%) (Najmi et al., 2012). Reduction in FBG, PPBG, HbA1C were more ( $\mathrm{P}$ value $<0.001$ ) in Nigella sativa group as compared to standard group Significant improvement in $\mathrm{HbA1C}$ indicates that Nigella sativa can be used as add on therapy to those patients whose glycemic control cannot be achieved by conventional drugs. Reduction in LDL cholesterol was more (P value $<0.001)$ in Nigella sativa group (NS) as compared to standard group (Najmi et al., 2012). These results were the same as reported previously in various studies. Insulin resistance leads to the overproduction of very low density lipoproteins (VLDLs) and to reduced lipoprotein lipase activity, thereby resulting in dyslipidemia. Therefore, attainment of better glycemic control may improve the lipid profile (Najmi et al., 2012). The presence of various unsaturated fatty acids like Arachidonic, eicosadienoic, linoleic, linolenic, oleic and almitoleic acid (Najmi et al., 2012; El. D. M et al., 2000), may be responsible for the improvement of lipid profile. The various mechanisms were proposed for the lowering of cholesterol. The seeds may either inhibit de novo cholesterol synthesis or stimulate bile acid excretion. It is well-known that both effects would lead to a decrease in serum cholesterol (Najmi et al., 2012; Beynen et al., 1987). These results confirmed that Nigella sativa can be used as add on drug therapy in patients of metabolic syndrome with poor glycemic control (Najmi et al., 2012).

The cholesterol lowering effect of $N$. sativa may be attributed to the presence of phytosterols like Beta-sitosterol, polyunsaturated fatty acids and its antioxidant activity. $N$. sativa may be able to reduce synthesis of cholesterol by hepatocytes and lower its absorption from the small intestine (Sabzghabaee et al., 2012, De Jong et al., 2003); it may also activate LDL-receptor by decreasing intracellular cholesterol, which leads to rapid clearance of LDL-cholesterol from blood circulation (Bamosa et al., 1997). The effect of $N$. sativa on increasing cholesterol secretion in the bile is another probable mechanisms witch can enhance its cholesterol lowering properties (Ibraheim Z, 2002).

Although Bamosa et al., 1997, worked on effects of daily oral ingestion of $2 \mathrm{~g} \mathrm{~N}$. sativa on some blood parameters for 2 weeks and reported a pattern of decreased levels of FBS and cholesterol on 16 second year medical students but there was no significant decrease in triglyceride level (Bamosa et al., 1997).

\section{CONCLUSION}

This systematic review on 14 studies demonstrated that Nigella sativa supplement in different doses and durations can improve lipid profiles in humans either with hyperlipidemia alone or associated with other conditions as diabetes mellitus and metabolic syndrome. However, the effect of this supplement is more pronounced on levels of TC, LDL, than on TG, HDL. Therefore, it is suggested that consumption of Nigella sativa supplementation be considered as a complementary treatment protocol for many diseases, especially hyperlipidemia and metabolic disorders. Although, NS can be used as a complementary therapies in cases related to hyperlipidemia, but due to differences in models, chemical compositions of difference sources of NS, dosage, and duration of intervention, it is difficult to determine effective type and dosage of NS. More studies are suggested to clarify effective type and dosage of NS in patients with hyperlipidemia.

\section{ACKNOWLEDGEMENT}

The authors would like to express appreciation to all reviewers who have been worked hardly to help authors in reading 
and classification of the articles and for their support in this review.

\section{Financial support and sponsorship: Nil.}

Conflict of Interests: There are no conflicts of interest.

\section{REFERENCES}

Abdel-Salam BK. Immunomodulatory effects of black seeds and garlic on alloxan-induced diabetes in albino rat. Allergol Immunopathol (Madr) 2012; 40(6): 336-340.

Abdel-Zaher AO, Abdel-Rahman MS, Elwasei FM. Protective Neurotoxicology 2011; 32(6): 725-733.

Bamosa AO, Basil A. Ali, Saleh A. Sowayan. Effect of oral ingeation of Nigella sativa seeds on some blood parameters. Saudi Pharmaceutical Journal 1997; 5(2-3): 126-129.

Ahmad, A., Husain, A., Mujeeb, M., Khan, S. A., Najmi, A. K., Siddique, N. A., \& Anwar, F. A review on therapeutic potential of Nigella sativa: A miracle herb. Asian Pacific journal of tropical biomedicine 2013; 3(5): 337-352.

Najmi A, Nasiruddin M, Khan RA, Haque SF. Effect of Nigella sativa oil on various clinical and biochemical parameters of insulin resistance syndrome. Int J Diabetes Dev Ctries 2008; 28(1): 11-14.

Najmi A, Nasiruddin M, Khan RA, Haque SF. Therapeutic effect of Nigella sativa in patients of poor glycemic control. Asian J Pharm Clin Res 2012; 5(Suppl 3): 224-228.

AJA Hmza, MT Osman, A Adnan, E Omar. Immunomodulatory effect of Nigella sativa oil in the disease process of type 1 diabetic rats. Research Journal of Pharmaceutical, Biological and Chemical Sciences 2013; 4(1): 980- 988.

AJA Hmza, E Omar, A Adnan, MT Osman. Nigella sativa oil has significant repairing ability of damaged pancreatic tissue occurs in induced type 1 diabetes mellitus. Global Journal of Pharmacology 2013; 7 (1), 14-19.

Al-Ali A, Alkhawajah AA, Randhawa MA, Shaikh NA. Oral and intraperitoneal LD50 of thymoquinone, an active principle of Nigella sativa, in mice and rats. J Ayub Med Coll Abbottabad 2008; 20(2): 25-27.

Sabzghabaee AM, Dianatkhah M, Sarrafzadegan N, Asgary S, Ghannadi A. Clinical Evaluation of Nigella sativa Seeds for the Treatment of Hyperlipidemia: a Randomized, Placebo Controlled Clinical Trial. Med Arh. 2012; 66(3): 198-200.

Assayed ME. Radioprotective effects of black seed (Nigella sativa) oil against hemopoietic damage and immunosuppression in gamma-irradiated rats. Immuno pharmacol Immunotoxicol 2010; 32(2): 284-296.

Beynen, A.C., M.B. Katan and L.F.M. Van Zutphen. Hypo-and hyperresponders: individual differences in the response of serum cholesterol concentration to changes in diet. Adv.Lipid Res., 1987; 22: 115-171.

Boskabady MH, Mohsenpoor N, Takaloo L. Antiasthmatic effect of Nigella sativain airways of asthmatic patients. Phytomedicine 2010; 17(10): 707-713.

Dehkordi FR, Kamkhah AF. Antihypertensive effect of Nigella sativa seed extract in patients with mild hypertension. Fundamental \& Clinical Pharmacology 2008; 22(4): 447-452.

De Jong A, Plat J, Mensink RP. Metabolic effects of plant sterols and stanols (Review) .J Nutri Biochem. 2003; 14: 362-369.

Datau EA, Wardhana, Eko E. Surachmanto, K. Pandelaki, J.A. Langi, Fias. Efficacy of Nigella sativa on Serum Free Testosterone and Metabolic Disturbances in Central Obese Male. Indones J Intern Med 2010; 42(3): 130-134.

El, D. M., N. I. Mady, et al. Nigella sativa L. oil protects against induced hepatotoxicity and improves serum lipid profile in rats. Arzneimittel Forschung. 2000; 50(9): 832-836. : Faculty of Medicine, Department of Pharmacology and Drug Toxicology, Alexandria University, Alexandria, 21521, Egypt.
Expert Panel on Detection, Evaluation, and Treatment of High Blood Cholesterol in Adults. Executive Summary of the Third Report of the National Cholesterol Education Program (NCEP) Expert Panel on Detection, Evaluation, and Treatment of High Blood Cholesterol in Adults (Adult Treatment Panel III). JAMA. 2001; 285(19):2486-2497.

Farzaneh, E., Nia, F. R.,Mehrtash, M., Mirmoeini, F. S., \& Jalilvand, M. The effects of 8-week Nigella sativa supplementation and aerobic training on lipid profile and VO2 max in sedentary overweight females. International journal of preventive medicine 2014; 5, 210.

Goreja WG. Black seed: nature's miracle remedy. New York, NY 7 Amazing Herbs Press; 2003.

Graham, I., Atar, D., Borch-Johnsen, K., Boysen, G., Burell, G., Cifkova, R., \& Hemingway, H. European guidelines on cardiovascular disease prevention in clinical practice: executive summary. European heart journal 2007; 28(19):2375-2414.

Hassanien MF. Investigation on lipid composition and functional properties of some exotic oilseeds. Thesis for doctoral dissertation accepted by: Technical University of Berlin, School of process sciences and engineering, 2004.

Kaatabi H, Bamosa AO, Lebda FM, Al Elq AH, Al-Sultan AI. Favorable impact of Nigella sativa seeds on lipid profile in type 2 diabetic patients. Journal of Family and Community Medicine 2012; 19 (3): 155161.

Ibrahim et al: : A randomised controlled trial on hypolipidemic effects of Nigella sativa seeds powder in menopausal women. Journal of Translational Medicine 2014; 12:82.

Ibraheim Z. Effect of Nigella sativa seeds and total oil on some blood parameters in female volunteers. saudi pharm J. 2002; 10: 54-59.

Bhatii IU, Rehman F, Khan MA, Marwat SK. Effect of prophetic medicine Kalonji (Nigella sativa L.) on lipid profile of human beings: An in vivo approach. World Applied Sciences Journal 2009; 6(8): 1053-1057.

Heshmati J, Namazi N, Memarzadeh MR, Taghizadeh M, Kolahdooz F. Nigella sativa oil affects glucose metabolism and lipid concentrations in patients with type 2 diabetes: A randomized, doubleblind placebo-controlled trial. Food Research International 2015; 70: 8793.

Khaled AAS. Gastroprotective effects of Nigella sativaoil on the formation of stress gastritis in hypothyroidal rats. Int $\mathrm{J}$ Physiol Pathophysiol Pharmacol 2009; 1: 143-149.

Last AR, Ference JD, Falleroni J. Pharmacologic treatment of hyperlipidemia. American family physician. 2011; 84(5):551.

Maron DJ, Fazio S, Linton MF. Current perspectives on statins. Circulation. 2000; 101(2):207-13.

Mohtashami A, Entezari MH. Effects of Nigella sativa supplementation on blood parameters and anthropometric indices in adults: A systematic review on clinical trials. J Res Med Sci 2016; 21:3.

Ahmed MM, El-Shamy KA, El-Nabarawy SK, Elbaiomy MA, El-Qattan GM. Nigella sativa Tea Improved Serum Paraoxonase-1 Activity, Glycemic Control and Lipid Profile in Type 2 Diabetes Mellitus Journal of Applied Sciences Research 2012; 8(12): 5897-5902.

Morikawa $\mathrm{T}, \mathrm{Xu} \mathrm{F}$, Ninomiya $\mathrm{K}$, Matsuda $\mathrm{H}$, et al. Nigellamines A3, A4, A5, and C, new dolabellane- type diterpene alkaloids, with lipid metabolism promoting activities from the Egyptian medicinal food black cumin. Chem Pharm Bull (Tokyo). 2004; 52: 494-7.

Navar-Boggan AM, Peterson ED, D'Agostino RB, Neely B, Sniderman AD, Pencina MJ. Hyperlipidemia in early adulthood increases long-term risk of coronary heart disease. Circulation. 2015: 114: 012477.

Newman TB, Hulley SB. Carcinogenicity of lipid-lowering drugs. JAMA. 1996; 275: 55-60.

Nickavar B, Majab F, Jaridnia K, et al. Chemical composition of the fixed and volatile oils of Nigella sativa L. from Iran. Z Naturforsch [C]. 2003; 58:629-31.

Qibi NM, Rami M.. A. Al--Hayali \& Hazim A. Mohammad. Effect of Nigella sativa (Black seed) on the serum lipids of healthy individuals. JBMS 2006; 6: 10 -15.

Qidwai W, Hamza HB, Qureshi R, Gilani A. Effectiveness, safety, and tolerability of powdered Nigella sativa (kalonji) seed in 
capsules on serum lipid levels, blood sugar, blood pressure, and body weight in adults: results of a randomized, double-blind controlled trial. J Altern Complement Med. 2009; 15(6): 639-644.

Tong IL: Non pharmacological treatment of postmenopausal symptoms. The Obstetrician \& Gynaecologist 2013, 15:19-25.

Tasawar Z, Siraj Z, Ahmad N, Lashri MH. The effect of Nigella sativa (Kalonji) on lipid profile in patients with stable coronary artery disease in Multanm Pakistan. Pakistan Journal of Nutrition 2011; 10(2): 162-167.

\section{How to cite this article:}

Al-Naggar RA, Osman MT, Mohamed IN, Aripin KNB, Abdulghani MAM. Effect of Nigella sativa supplementation on human lipids: systematic review. J App Pharm Sci, 2017; 7 (04): 213-219. 